\title{
„Vidia ma?" Zdanie, že sa niekto pozerá, zvyšuje čestnost' v modifikovanej hre Diktátor
}

\section{„Do They See Me?" Cues of Being Watched Enhance Honesty in Modified Dictator Game}

\author{
Andrej Mentel, Romana Žhlavníková
}

\begin{abstract}
We examined the effect of the mirror in front of participants on honesty in the modified Dictator game with the explicit rule "Take one item of reward only". We expected that participants will transgress the rule significantly less in the presence of mirror. In first study, a group of preschool children underwent the task in the within-subject repeated measures design; the experimental condition was used two weeks after the pretest. In second study, a between-subject design was used to a group of university students. In both cases, our results show highly significant odds ratio of the preventing the transgressing the rule. These results are higher than those known from studies based on simple Dictator game, what suggests that the process of self-evaluation triggered by objective self-awareness may play an important role in this setting.
\end{abstract}

KEYWORDS Altruism, reciprocity, reputation, mirror, Dictator game, objective self-awareness

Altruistické správanie je jednou z vel'kých hádaniek evolučnej psychológie a antropológie. Na prvý pohl'ad sa zdá zrejmé, že selekčný tlak bude uprednostňovat' takých jedincov, ktorí budú maximalizovat' svoje vlastné zisky a minimalizovat' náklady. Zdá sa preto na prvý pohl'ad paradoxné, aby sa ako evolučne úspešné stabilizovali také vzory správania, ktoré sú spojené s nákladmi vynaloženými v prospech niekoho druhého. Ukázalo sa však, že takýto pohl'ad na transakcie medzi členmi sociálnych skupín (či už l'udí alebo iných živočíchov) je príliš zjednodušujúci. L’udia sa pomerne často delia s druhými o zdroje a do istej miery aj dodržiavajú pravidlá určujúce, kol'ko si vziat' z verejného zdroja, aby ostalo aj pre d’alších. Zaujímavá je však otázka, čo ovplyvňuje tento druh správania. Kedy sa l'udia správajú „štedrejšie“, teda kedy sú ochotní obetovat' viac svojich zdrojov v prospech druhého? Alebo v inej situácii, kedy sú náchylnejší vziat' si skutočne len pridelený kúsok a neobohatit' sa na úkor ostatných? Viacero výskumov nasvedčuje, že k takémuto „štedrejšiemu“ či „,poctivejšiemu“ správaniu majú l’udia sklon hlavne vtedy, ked' u nich vznikne čo i len nejasný dojem, že môžu byt' pozorovaní (napr. Bateson, Nettle a Roberts 2006; Beaman, Klentz, Diener a Svanum 1979; s použitím sluchových podnetov Haley a Fessler 2005). Pritom tento dojem môže vzniknút' na základe automatického, nevedomého spracovania informácií o prostredí, v ktorom sa nachádza. Staršie výskumy (zhrnutie pozri v Nettle et al. 2013)

Sociální studia. Katedra sociologie FSS MU, 4/2015. S. 19-30. ISSN 1214-813X. 
ukazujú, že na vyvolanie tohto efektu stačí do zorného pol’a účastníka experimentu umiestnit' obrázok očí alebo zrkadlo; podl'a všetkého nie je dôležité, že na vedomej úrovni participant vyhodnotí daný obraz ako „len obrázok“ alebo „len svoj vlastný obraz“. Ciel’om tohto článku je tieto výsledky nielen zreprodukovat', ale aj pozmenit' parametre úlohy tak, aby sme mohli lepšie posúdit' vplyv jedného hypotetického mechanizmu. Ten podl'a nás spočíva $\mathrm{v}$ tom, že účastníci experimentu sa usilujú na jednej strane podporit' svoju reputáciu štedrých, altruistických, ale najmä ku kooperácii ochotných l'udí, na druhej strane sa však snažia potlačit' šírenie negatívnej reputácie ako l'udí so sklonom porušovat' pravidlá. Domnievame sa, že klasický formát úlohy zodpovedá len prvému aspektu budovania reputácie, ale druhý ponecháva ako implicitný; v našej modifikácii úlohy cielene zahŕňame oba aspekty.

Doterajšie experimenty zamerané na výskum faktorov ovplyvňujúcich štedrost' rozhodnutí boli založené hlavne na paradigme hry Diktátor (angl. Dictator game), zriedkavejšie na iných ekonomických hrách (napr. Hra verejných statkov - angl. Public goods game). V hre Diktátor mali participanti v role „darcov“ pridelit' „príjemcom“ nejakú čast' z celkovej sumy, pričom príjemca nemal žiaden vplyv na rozhodnutie darcu. Zvyšok z danej sumy by potom pripadol darcovi. Je zrejmé, že pri jednorazovej hre by malo byt’ pre „darcu“ najvýhodnejšie nepridelit' príjemcovi nič a vziat' si všetko (prípadne pridelit' len najmenší možný diel). Napriek tomu sa ukazuje, že $\mathrm{v}$ experimentálnej situácii takto l'udia zvyčajne nepostupujú; typicky pridel'ujú príjemcom väčší než len minimálny možný diel, a to aj v jednorazových hrách zabezpečujúcich participantom úplnú anonymitu (Fehr a Gächter 2002; Henrich et al. 2001). Navyše, výška pridelenej sumy závisí od rôznych sociálnych faktorov. Jedným z takýchto faktorov podporujúcich štedrejšie rozhodnutie je prítomnost' svedkov (Bull a Gibson-Robinson 1981; Kurzban 2001). Pomerne prekvapujúce je však zistenie, že štedrost' v ekonomických experimentoch ovplyvňujú aj stimuly, ktoré len v náznakoch pripomínajú pozorujúce oči. Haley a Fessler (2005) vo svojej kl’učovej štúdii ukázali, že na to, aby participanti signifikantne zvýšili sumy ponúknuté anonymným príjemcom v hre Diktátor, stačí, aby sa v priestore, kde experiment prebieha, umiestnil obrázok - kresba očí, ktorá ani nemusí byt' príliš realistická. Tieto výsledky sa opakovane potvrdili v rôznych kontextoch, teda v laboratórnych aj naturalistických podmienkach, u rôznych sociálnych skupín a pri rôznych variantoch ekonomických hier, ktoré výskumníci použili (metaanalýzu vid' v práci Nettle et al. 2013). Je iba málo výskumných prác, v ktorých sa daný jav nepotvrdil. Jedným z príkladov je japonská štúdia využívajúca ako podnet simulujúci pohl’ad svedka nastavené zrkadlo (Niwa, Hiraishi a Oda 2011). Hoci je negatívny výsledok v tomto druhu experimentov zriedkavý, podl'a nášho názoru poukazuje na dôležitý aspekt javu, kvôli ktorému sme sa rozhodli pozmenit' úlohu, ktorú v experimentoch zadávame participantom. Viedli nás k tomu úvahy o pravdepodobnom mechanizme, ktorý spôsobuje výsledky opísané $\mathrm{v}$ literatúre.

V pôvodnej verzii experimentu, ktorá je založená na paradigme hry Diktátor, môžeme očakávat' dva zdroje motivácie $\mathrm{v}$ prospech prosociálneho správania, pokial' u participanta vznikne hoci aj nejasný dojem, že je pozorovaný. Oba tieto zdroje motivácie sú založené na tom, aká povest' (reputácia) sa rozšíri o danom hráčovi. Ak totiž vyjdeme z hypotézy recipročného altruizmu (pôvodne Trivers 1971), potom selekčný tlak uprednostňuje tých jednotlivcov, ktorí na kooperáciu ponúknutú iným hráčom odpovedajú v d'alšom kole 
kooperáciou (a naopak, na neochotu kooperovat' odpovedajú odmietnutím kooperácie). Odplata však nemusí nasledovat' bezprostredne po poskytnutej (resp. odmietnutej) pomoci, preto je dôležité pre členov spoločenstva mapovat' históriu výmen a pamätat' si správanie jednotlivých hráčov. Prvým zdrojom motivácie konat prosociálne v situácii „domnelého pozorovania svedkom“ by teda mala byt' táto investícia do vytvárania reputácie štedrého hráča (Wedekind a Braithwaite 2002). Niwa, Hiraishi a Oda (2011) tu však zmieňujú aj druhý, tzv. negatívny zdroj motivácie, ktorý je založený na snahe vyhnút' sa rozšíreniu povesti o sebe ako o porušovatel'ovi noriem (Gintis, Bowles, Boyd a Fehr 2005).

Podl'a nášho názoru však $\mathrm{v}$ pokusoch založených na hre Diktátor nie je druhý typ motivácie zastúpený dostatočne silno; hypotetické pravidlo nabádajúce $\mathrm{k}$ štedrej ponuke je tu prítomné v lepšom prípade len implicitne. Zdá sa teda, že hoci je citovaný japonský výskum (Niwa, Hiraishi a Oda 2011) pomerne ojedinelý tým, že v experimente $\mathrm{s}$ „domnelým svedkom“ pri hre Diktátor nezaznamenal signifikantný rozdiel oproti kontrolnej skupine, poukazuje na dôležitú stránku skúmaného javu. $Z$ doterajších výskumov vôbec nie je zrejmé, či je vôbec v skúmaných skupinách rozšírená (a do akej miery je internalizovaná) štedrost' ako sociálna norma. Rozhodli sme sa preto túto stránku posilnit' tým, že sme úlohu preformulovali do podoby s explicitne vysloveným pravidlom. $\mathrm{V}$ našom výskume teda účastník nemal z ponúknutej sumy čast' pridelit' anonymnému príjemcovi, ale naopak - z ponúknutého množstva drobných predmetov si mal vziat' práve jeden. Je zrejmé, že v situácii, ked' je participant presvedčený, že sa „nikto nepozerá“ a že experimentátori ani ostatní hráči nemajú šancu zaregistrovat' porušenie tohto pravidla, by bolo výhodnejšie pravidlo jednoducho ignorovat'. Ak však platí, čo zistili Gintis, Bowles, Boyd a Fehr (2005), potom aj vyvolanie nevedomého dojmu, že účastníka experimentu niekto pozoruje, by malo zvýšit' šance, že dané pravidlo dodrží.

Vyššie sme ukázali, že obe zmienené stránky budovania reputácie v skupine tvoria východisko pre ultimátne (finálne, resp. funkčné) vysvetlenie javu, ked’ sa človek v situácii so „zdanlivým svedkom“ správa prosociálnejšie, než ked' nemá dôvod pochybovat' o tom, že je sám. V našom výskume sa však chceme zamerat' viac na tú stránku motivácie k prosociálnemu správaniu, ktorá predpokladá, že človek sa bude snažit' zamedzit' vzniku reputácie „porušovatel'a noriem“. Pri nej totiž môžeme sformulovat' aj hypotézu o mechanizme, ktorým sa to pravdepodobne deje. Začiatkom 70. rokov 20. storočia vydali Duval a Wicklund (1972) knihu, v ktorej popísali jav, ktorý nazvali objektívne sebauvedomovanie (objective self-awareness; podrobnejšie v Žihlavníková, Mentel a Tuf 2014). Podl’a nich, ak zameriame svoju pozornost' na seba, vyvolá to proces porovnávania svojho vlastného správania so štandardmi, ktoré by sme mali spĺn̆at'. Ak sa objaví nesúlad medzi vlastným správaním a internalizovanými štandardmi, snažíme sa bud' presmerovat' pozornost' inde, alebo zmenit' správanie tak, aby nebolo $\mathrm{v}$ rozpore so štandardom. Tento proces mohli podporit' stimuly ako napríklad umiestnenie zrkadla pred účastníka výskumu alebo prehrávanie záznamu jeho vlastného hlasu. Účastníci, ktorí riešili test zameraný na prešmyčky priamo pred zrkadlom, pričom im experimentátori púšt’ali ich vlastný hlas, podvádzali menej než tí, ktorí sedeli obd’aleč od zrkadla a počuli nahrávku hlasu iného človeka (Diener a Wallbom 1976). Objavuje sa tu však otázka, či je k hodnoteniu vlastného správania potrebné vedomé uvedomovanie si samého seba (consciouss self-awareness), alebo nie. Zdá sa, že tento proces 
môže prebiehat' spontánne, rýchlo a nezávisle na vedomej aktivite, hoci je jedinec schopný hodnotit' vlastné správanie aj vedome (Silvia a Phillips 2013).

Ilúzia, že „niekto sa pozerá“, má pravdepodobne neurofyziologické základy. Zdá sa, že existuje štruktúra $v$ mozgu (pravostranný gyrus fusiformis), ktorá sa aktivizuje špecificky $\mathrm{v}$ prípade, že človek vníma zrakové podnety pripomínajúce l’udskú tvár (dokonca aj v prípade, že ide o pareidóliu; Liu et al. 2014). Je možné, že aktivizácia tejto štruktúry na základe vnemu kresby očí alebo vlastného obrazu v zrkadle spúšt’a kaskádu procesov, ktoré vyvolávajú ilúziu, že jednotlivec je niekým pozorovaný/videný a ktoré napokon ústia do automatického (implicitného) posudzovania vlastného správania.

Predpokladajme teda, že ilúzia, že účastník experimentu je videný, skutočne u neho spustí proces implicitného objektívneho sebauvedomovania. Ak je to tak, potom môžeme predpokladat', že toto sebauvedomovanie posilňuje tú stránku budovania reputácie, ktorá sa týka presvedčenia, že participant nie je porušovatel'om noriem. Domnievame sa však, že experimenty založené na klasickej hre Diktátor sa týkajú hlavne druhej stránky budovania reputácie, a to, že participant je ochotný kooperovat' a robit' altruistické činy. Naznačujú to aj doterajšie výsledky kvantifikujúce vel'kost’ účinku prítomnosti „zdanlivého svedka“. Nettle et al. (2013) uvádzajú vo svojom zhrnutí viacerých výskumov zameraných na efekt „pozerajúcich sa očí“ pri hre Diktátor zvýšenie šancí darovania max. 3,35násobne, pričom celkový pomer šancí vypočítaný zo všetkých výskumov bol len 1,39 (Nettle et al. 2013: 38). Ak je pravda, že v prípade dodržiavania pravidla ide o budovanie oboch stránok reputácie, potom očakávame vy̌̌šiu mieru vplyvu.

Ciel'om nášho výskumu je experimentálne overit' hypotézy vyplývajúce z evolučnopsychologickej teórie altruizmu založeného na budovaní reputácie. Táto teória predpokladá, že tzv. altruistické správanie je motivované úsilím zlepšit’ reputáciu jednotlivca. To sa deje na dvoch úrovniach: podpora pozitívnej reputácie (,som ochotný kooperovat $\left.{ }^{\star}\right)$, no aj popretie negatívnej reputácie (,porušujem pravidlä“). Ked’že do systému uvádzame novú vlastnost' (explicitnú formuláciu pravidla, ktoré je možné dodržat' alebo porušit'), nejde len o replikáciu starších výskumov, ale aj o dôležitú inováciu.

Ked’že $\mathrm{v}$ našich experimentoch sú zastúpené oba aspekty budovania reputácie, našou hypotézou je, že efekt ,zdanlivého svedka“ sa prejaví silnejšie než pri pokusoch s klasickou hrou Diktátor. V prvom rade, očakávame zamietnutie nulovej hypotézy, že šance dodržania pravidla (,Vezmi si len jeden kus odmeny!“) sú rovnaké v prítomnosti zrkadla ako bez neho. V druhom rade, očakávame, že toto zvýšenie šancí bude vyššie, než sa zistilo vo výskumoch s hrou Diktátor, teda výrazne vyššie šance „poctivého“ správania v prítomnosti nastaveného zrkadla.

\section{Vzorka a metódy zberu dát}

Výskum sme uskutočnili formou dvoch štúdií, ktoré sa líšili výskumným dizajnom a vekovou skupinou participantov. Prvá štúdia bola vykonaná na vzorke detí predškolského veku $\mathrm{z}$ troch materských škôl $\mathrm{v}$ Košiciach $(\mathrm{N}=45, \mathrm{z}$ toho 21 dievčat; zo vzorky bolo neskôr jedno diet’a vylúčené pre porušenie pravidiel. Vekové rozmedzie bolo 5-6 rokov). Predškolské deti sme v prvej štúdii zvolili na základe poznatkov o morálnom vývoji. U predškolských 
detí sú autoritou určujúcou pravidlá dospelí, pričom vel’mi záleží na tom, či je daný dospelý práve prítomný. Motiváciou k dodržaniu pravidla je úsilie vyhnút' sa negatívnemu hodnoteniu, resp. dosiahnut' pozitívnu odozvu, napr. pochvalu (Vágnerová 2008). Na základe týchto charakteristík sme očakávali, že vytvorenie podvedomého dojmu „niekto ma vidí“ bude mat' silnejší, a teda l'ahšie pozorovatelný účinok než u dospelých. Navyše, predpokladali sme, že predškolské deti ešte nemajú kognitívne schopnosti rozvinuté natol'ko, aby dokázali odhalit' pointu experimentu a prispôsobit' mu svoje správanie. Ked’že nám ich zriad'ovatel', teda Magistrát mesta Košice, nepovolil vstup do viacerých materských škôl, rozhodli sme sa vzhl'adom na malú vel'kost' vzorky použit' usporiadanie s opakovanými meraniami. Šlo teda o predexperimentálne usporiadanie $\mathrm{s}$ jednou skupinou a s dvomi administráciami (withinsubject design). Deti si mali po splnení jednoduchej úlohy íst' vziat' malú odmenu (cukrík) do susednej miestnosti. Boli však upozornené, že si smú vziat' len jeden cukrík. Správanie sa detí v miestnosti bolo nahrávané na videozáznam tak, aby nebolo možné diet’a identifikovat', ale aby bolo možné zachytit', či diet’a dodržalo pravidlo, alebo nie. O dva týždne na to deti absolvovali opätovnú administráciu experimentu, no do miestnosti, v ktorej sa nachádzala odmena, pribudlo zrkadlo. Diet’a, ktoré si bralo odmenu, tak mohlo vidiet' svoj vlastný obraz v zrkadle.

Opakovaná administrácia $\mathrm{s}$ tými istými účastníkmi má mnoho nevýhod $\mathrm{z}$ hladiska dôkazu kauzálneho vplyvu intervencie. Aby sme aspoň obmedzili ich vplyv, s učitel'kami aj rodičmi sme boli dohodnutí, že sa počas experimentu nebudú s det'mi o ňom rozprávat' (isteže, nebolo v našich silách overit', či dohodu dodržali). Rozobrat' to mali s det'mi až po druhej administrácii. U jedného z detí sme však zistili porušenie tejto dohody, takže sme ho vylúčili z druhej administrácie. Pochopitel'ne, nemali sme vplyv na to, či sa o pokuse deti rozprávali spontánne. To sa mohlo stat rušivou premennou ovplyvňujúcou výsledky v následnej administrácii.

Druhá štúdia sa uskutočnila na Univerzite Palackého v Olomouci a vzorku tvorili vysokoškolskí študenti viacerých odborov $(\mathrm{N}=82$, z toho 42 žien). Vysokoškoláci predstavovali vol'bu vedenú dvomi kritériami: po prvé, po tom, ako sa ukázalo na vzorke predškolských detí, že k očakávanému efektu dochádza, chceli sme našu hypotézu overit’ aj u dospelých. Druhým kritériom bola dostupnost'. Výhodou pri výskumu na malej vzorke je jej relatívna homogenita vzhl'adom na vek, a pravdepodobne aj d'alšie sociodemografické ukazovatele. Vek participantov bol v rozmedzí od 19 do 24 rokov, presnejšie údaje však nemáme kvôli dosiahnutiu maximálneho možného stupňa anonymity. Pri anonymite nejde len o faktický stav, pri ktorom experimentátori nedokážu spojit' dáta s konkrétnymi jednotlivcami; v podstatnej miere ide o to, aby účastníci nenadobudli ani náznak podozrenia, že by sa takéto stotožnenie dalo dodatočne urobit'. Väčšia vzorka než v prvej štúdii umožnila experimentálne usporiadanie s náhodným pridelením participantov do pracovnej a kontrolnej skupiny (between-subject design). Ked’že v tomto prípade šlo o porovnanie medzi skupinami, do ktorých boli participanti zadelení náhodne, vyhli sme sa problémom s opakovaným testovaním. Účastníci najskôr dostali za úlohu vyriešit’ tzv. test cesty (Trail making test). Tento test sme zvolili preto, že neodhal'uje žiadne osobné údaje o účastníkovi, na základe ktorých by mohol byt' neskôr čo i len približne identifikovaný. Naším zámerom totiž bolo dat' im l'ubovol'nú úlohu, po splnení ktorej si budú môct' vziat' odmenu. Odmena sa nachádzala 
v inej miestnosti než „testovanie“. Ako odmenu si mali vziat' jeden z drobných predmetov (cukrovinky, perá, cigarety atd'.) v susednej miestnosti; bolo im zdôraznené pravidlo, že si smú vziat' len jeden kus. To, čo si vzali, bolo jedinou odmenou za účast' v experimente. Rovnako ako $\mathrm{v}$ prvej štúdii, aj $\mathrm{v}$ tejto bola intervenciou prítomnost' zrkadla $\mathrm{v}$ miestnosti s odmenou. Rozmery zrkadla boli približne $55 \times 30 \mathrm{~cm}$ a bolo umiestnené tak, aby účastník videl svoj vlastný obraz počas brania si odmeny.

Nulovou hypotézou je, že $\mathrm{v}$ oboch štúdiách nebude štatisticky signifikantný rozdiel medzi pravdepodobnost'ou dodržania pravidla „vziat' si len jeden kus odmeny“ v situácii bez zrkadla v porovnaní so situáciou so zrkadlom. Ak však platí, že v človeku stačí vyvolat' ilúziu, že je pozorovaný (hoci aj vystavením vlastnému obrazu v zrkadle), mali by sme túto nulovú hypotézu zamietnut'.

\section{Metódy analýzy}

V oboch štúdiách posudzujeme zmenu šancí (odds), že participanti dodržia pravidlo, pričom očakávame, že táto zmena je vyvolaná prítomnost'ou vlastného obrazu v zrkadle v porovnaní so situáciou bez neho. Mierou tejto zmeny je pomer šancí (odds ratio). Ak by nebol rozdiel medzi frekvenciou dodržania pravidla $\mathrm{v}$ experimentálnej a kontrolnej skupine, potom by sa pomer šancí mal blížit hodnote 1. Čím „účinnejši“ “ je pôsobiaci faktor, tým vyššiu hodnotu nadobudne pomer šancí.

Naše dve štúdie sa však líšia usporiadaním, z čoho vyplýva potreba odlišnej metódy odhadu pomeru šancí. V prvej štúdii ide o párové merania. Pre každého participanta teda máme $\mathrm{k}$ dispozícii dve hodnoty závislej premennej, a to správanie za podmienky bez prítomného zrkadla a následne správanie $\mathrm{v}$ prítomnosti zrkadla. Za oboch podmienok mohol daný participant bud' dodržat' pravidlo „smieš si vziat' len jednu odmenu“, alebo ho nedodržat'. Mohla tak vzniknút' štvorica kombinácií správania. Početnosti jednotlivých kombinácií zaznamenávame v podobe kontingenčnej tabul'ky (Tabulka A.1, vid' Príloha). V Prílohe uvádzame aj matematické vzt’ahy potrebné na výpočet jednotlivých potrebných štatistík. Podobne aj pre druhú štúdiu založenú na dvoch skupinách uvádzame v Prílohe všeobecný tvar kontingenčnej tabul'ky (Tabulka A.2) aj postup výpočtu príslušných štatistík.

\section{Výsledky}

Ako sme písali vyššie, v oboch prípadoch je nezávisle premennou (faktorom) prítomnost' zrkadla v miestnosti s odmenou, takže participant mohol vidiet' svoj obraz počas toho, ako si bral odmenu. Závisle premennou (výsledkom) bolo poslúchnutie, resp. porušenie pravidla, ktoré spočívalo v tom, že každý si smel vziat' len jeden kus odmeny. Ide teda o vzt’ah dvoch dichotomických premenných.

V prvej štúdii (predškoláci z troch košických materských škôl) sme pri druhej administrácii pozorovali vel'mi výrazný posun smerom k dodržiavaniu pravidla (Tabulka 1). Pomer šancí počítaný ako podiel diskordantných dvojíc je $\mathrm{OR}=11$. Isteže, bolo to dané hlavne tým, že len jeden participant z 27, ktorí v prvom kole vyhoveli pravidlu, ho v druhom kole porušil. Za týchto okolností z-skóre nadobúda hodnotu $\mathrm{z}=2,296$, čomu zodpovedá 
$\mathrm{p}<0,012$. Aj odhad hraníc 95percentného intervalu spol'ahlivosti naznačuje, že pomer šancí je väčší ako 1: $\mathrm{CI}=<1,43 ; 85,2>$. Aj napriek relatívne malej vzorke poskytuje post-hoc odhad štatistickej sily vel'mi vysokú hodnotu $(1-\beta>0,99)$.

Tabul'ka 1: Kontingenčná tabul'ka výsledkov pri párovom dizajne: materská škola

\begin{tabular}{|l|l|c|c|}
\hline & & \multicolumn{2}{|c|}{ Posttest: So zrkadlom } \\
\hline & & Porušil pravidlo & Vyhovel pravidlu \\
\hline \multirow{2}{*}{ Pretest: Bez zrkadla } & Porušl pravidlo & 6 & 11 \\
\cline { 2 - 4 } & Vyhovel pravidlu & 1 & 26 \\
\hline
\end{tabular}

Výsledky druhej štúdie (študenti Univerzity Palackého v Olomouci) sú v súlade s prvou. Výsledky sú zhrnuté v kontingenčnej tabul'ke:

Tabul'ka 2: Kontingenčná tabul'ka pri experimentálnom dizajne: Študenti VŠ

\begin{tabular}{|l|l|c|c|}
\hline & & \multicolumn{2}{|c|}{ Výsledok } \\
\hline & & Porušil pravidlo & Vyhovel pravidlu \\
\hline \multirow{3}{*}{ Podmienka } & Kontrolná (bez zrkadla) & 17 & 25 \\
\cline { 2 - 4 } & $\begin{array}{l}\text { Experimentálna } \\
\text { (so zrkadlom) }\end{array}$ & 4 & 36 \\
\hline
\end{tabular}

V tomto prípade je pomer šancí $\mathrm{OR}=6,12$ a danej distribúcii početností v bunkách tabul'ky nadobúda $\mathrm{z}$-skóre hodnotu $\mathrm{z}=2,952$, čomu zodpovedá $\mathrm{p}<0,01$. Odhad hraníc 95\% intervalu spol'ahlivosti taktiež potvrdzuje, že pomer šancí je väčší ako $1: \mathrm{CI}=\langle 1,838 ; 20,376>$. Aj tomto prípade poskytuje post-hoc odhad štatistickej sily testu za daných podmienok hodnotu $1-\beta>0,99$.

\section{Diskusia a záver}

Zistenia z oboch experimentov sú $\mathrm{v}$ súlade so stanovenými hypotézami, ktoré sme si stanovili. V prítomnosti podnetu pripomínajúceho prítomnost' pozorovatel'a (v našom prípade nastaveného zrkadla) participanti skutočne dodržali dané pravidlo signifikantne častejšie než v situácii bez tohto podnetu. Okrem toho, pomer šancí, že v experimentálnej situácii participanti dodržia pravidlo, bol v skupine vysokoškolákov vyšší než 6 , čo je výrazne viac než v prípadoch, o ktorých referujú Nettle et al. (2013). Naše zistenia teda podporujú hypotézu, že aj podnet ako nastavené zrkadlo dokáže spustit' monitorovanie a vyhodnocovanie vlastného správania, čo prinajmenšom určitú čast' l'udí motivuje k rešpektovaniu daných pravidiel.

$\mathrm{K}$ týmto výsledkom sme došli na rozdielnych skupinách (u detí predškolského veku aj u vysokoškolákov) a vo dvoch rozdielnych usporiadaniach výskumu. Je zrejmé, že pri usporiadaní s jednou skupinou by mohla vzniknút' námietka, že pozorovaný jav môže byt' dôsledkom predbežnej administrácie; ak by sa deti po jeho uskutočnení rozprávali o experimente s učitel'kami, mohlo by ich to ovplyvnit' a v následnej administrácii by sa mohli aspoň 
niektoré z nich správat' odlišne, bez ohl'adu na prítomnost' nastaveného zrkadla. Zmienený problém je vo všeobecnosti kameňom úrazu pri usporiadaniach pracujúcich len s jednou skupinou participantov. Aj ked' v tomto usporiadaní zistíme výrazný rozdiel medzi administráciami bez intervencie a s ňou, neexistuje žiaden dôkaz, že rozdiel je spôsobený práve intervenciou. Aby sme sa vyhli tomuto problému, v druhej štúdii sme zvolili klasické experimentálne usporiadanie s dvomi skupinami (s náhodným zadelením subjektov) a len jednou administráciou. Výsledky však boli vel'mi podobné ako v prvej štúdii. Naše zistenia sú zároveň $\mathrm{v}$ súlade $\mathrm{s}$ mnohými dávnejšie publikovanými výskumami iných autorov (zhrnutie pozri Nettle et al. 2013). Zdá sa teda, že prítomnost' „zdanlivého svedka“ spravidla vedie $\mathrm{k}$ rôznym prejavom prosociálneho správania, $\mathrm{v}$ našom prípade $\mathrm{k}$ dodržaniu daného pravidla predpisujúceho sa uskromnit' napriek pokušeniu vziat' si viac.

Bolo by možné d’alej namietat', že teória popisujúca kauzálny mechanizmus sebaregulácie, ktorú sme si zvolili, nemusí byt' adekvátna. Táto námietka je určite opodstatnená. V skutočnosti na to, aby sme vysvetlili vyššiu mieru dodržania daného pravidla v situácii, kde u participantov vyvolávame nevedomý dojem, že sú pozorovaní, stačí uvažovat' všeobecne o mechanizme negatívnej spätnej väzby (pozri Žihlavníková, Mentel a Tuf 2014: 67). V princípe stačí identifikovat' proces, ktorý zabezpečuje reguláciu správania vd’aka neustálemu porovnávaniu aktuálneho správania voči ciel’u (resp. referenčnej hodnote). Ak aktuálne správanie nevedie k dosiahnutiu ciel’a, činnost' tohto „komparátora“ vyvolá zmenu správania. $\mathrm{V}$ tomto prístupe, na rozdiel od teórie objektívneho sebauvedomovania, nemusí figurovat' averzívne štádium (t.j. jednotlivec nemusí pocitovat' subjektívnu nepohodu z toho, že robí niečo, čo nepovažuje za prijatel'né). Teóriu objektívneho sebauvedomovania a s ňou spojenú hypotézu o averzívnom štádiu čiastočne podporujú výsledky vy̌šsie citovaného japonského výskumu. Účastníci, ktorí podstúpili hru Diktátor v prítomnosti nastaveného zrkadla, v dotazníku reportovali svoj zlý pocit z toho, že príjemcovi pridel’ujú menšiu sumu, než „,by mali““. Na druhej strane, ani vysoké skóre v tomto dotazníku nekorelovalo so sumou, ktorú v skutočnosti venovali príjemcovi (Niwa, Hiraishi a Oda 2011).

Existuje aj iné, omnoho jednoduchšie vysvetlenie, ktoré by mohlo byt' relevantné hlavne v skupine vysokoškolákov. Spočíva v tom, že čast' participantov mohla jednoducho „prekuknút"“ pointu experimentu a prispôsobit’ svoje správanie očakávaniu experimentátorov. Mohlo im byt' čudné, načo je $\mathrm{v}$ miestnosti s odmenou na stene zrkadlo. Táto námietka je zaiste relevantná, ale len t’ažko sa dá zapracovat' do usporiadania výskumu. Totiž aj tí, ktorí odhalili pointu experimentu, mohli prispôsobit' svoje správanie obomi smermi (k dodržaniu, alebo práve naopak - porušeniu pravidla). Domnievame sa, že neexistuje spôsob, ako to spol'ahlivo odfiltrovat'. Nepomohol by ani následný rozhovor alebo dotazník, pretože v ňom vyslovené odpovede môžu byt' len dodatočné racionalizácie.

Zaujímavou otázkou je, či budeme pozorovat' nejaký rozdiel medzi rôznymi druhmi podnetov použitých ako experimentálne podmienky $\mathrm{v}$ usporiadaniach podobných ako naša druhá štúdia opísaná v tomto článku. Ak platí, že aktivizácia pravostranného fusiformného závitu (gyrus fusiformis) nastáva aj v prípade podnetov vytvárajúcich ilúziu ludskej tváre (Liu et al. 2014), a ak táto aktivizácia stojí na začiatku kaskády procesov ústiacej do implicitného objektívneho sebauvedomovania, potom by efekt „niekto sa pozerá“ mali vyvolávat’ rôzne podnety. V doterajších výskumoch sa najčastejšie používali fotografie alebo kresby 
očí (Haley a Fessler 2005; Nettle et al. 2013 a pod.) alebo vlastný obraz v zrkadle (napr. Diener a Wallbom 1976; Niwa, Hiraishi a Oda 2011 atd'.). Na základe dát, ktoré sa nám zatial' podarilo nazbierat', sa zdá, že kresba očí vytvára porovnatel'ný efekt ako vlastný obraz v zrkadle, ale prítomnost' iných podnetov (dokonca ani fotografie tváre) nevedie k signifikantnému zvýšeniu šancí správania v súlade s daným pravidlom (Žihlavníková, Mentel a Tuf, v príprave). Tieto výsledky sú však len predbežné, ked’že zber dát nie je ešte ukončený.

Význam týchto zistení je v prvom rade teoretický, pretože prináša poznatky o faktoroch, ktoré môžu ovplyvňovat' morálne rozhodnutia. Zdanlivo ide o doménu, kde sme „,pánmi vo svojom dome“, teda kde sa rozhodujeme slobodne na základe vyhodnotenia situácie. Zdá sa však, že aj naoko bezvýznamné faktory dokážu naklonit’ pravdepodobnost' k takému či onakému rozhodnutiu pravdepodobne bez toho, aby si to participanti uvedomovali.

\section{Literatura}

BATESON, Melissa, Daniel NETTLE a Gilbert ROBERTS. 2006. „Cues of Being Watched Enhance Cooperation in a Real-World Setting." Biology Letters 2(3): 412-414.

BEAMAN, Arthur L., Bonnel KLENTZ, Edward DIENER a Soren SVANUM. 1979. „Self-Awareness and Transgression in Children: Two Field Studies." Journal of Personality and Social Psychology 37(10): 1835-1846.

BULL, Ray a Elisabeth GIBSON-ROBINSON. 1981. „The Influences of Eye-Gaze, Style of Dress, and Locality on the Amounts of Money Donated to a Charity." Human Relations 34(10): 895-905.

DIENER, Edward a Mark WALLBOM. 1976. „Effects of Self-Awareness on Antinormative Behavior.” Journal of Research in Personality 10(1): 107-111.

DUVAL, Shelley a Robert A. WICKLUND. 1972. A Theory of Objective Self-Awareness. New York: Academic Press.

FEHR, Ernst a Simon GÄCHTER. 2002. „Altruistic Punishment in Humans.” Nature 415: 137-140.

GINTIS, Herbert, Samuel BOWLES, Robert BOYD a Ernst FEHR. 2003. „Explaining Altruistic Behavior in Humans." Evolution and Human Behavior 24(2): 153-172.

HALEY, Kevin J. a Daniel M. T. FESSLER. 2005. „Nobody's Watching? Subtle Cues Affect Generosity in an Anonymous Economic Game." Evolution and Human Behavior 26(3): 245-256.

HENRICH, Joseph, Robert BOYD, Samuel BOWLES, Colin CAMERER, Ernst FEHR, Herbert GINTIS a Richard McELREATH. 2001. „In Search of Homo Economicus: Behavioral Experiments in 15 Small-Scale Societies." The American Economic Review 91(2): 73-78.

KIRKWOOD, Betty R. a Jonathan A. C. STERNE. 2003. Essential Medical Statistics. Malden: Blackwell.

KURZBAN, Robert. 2001. „The Social Psychophysics of Cooperation: Nonverbal Communication in a Public Goods Game.” Journal of Nonverbal Behavior 25(4): 241-259.

LIU, Jiangang, Jun LI, Lu FENG, Ling LI, Jie TIAN a Kang LEE. 2014. „Seeing Jesus in Toast: Neural and Behavioral Correlates of Face Pareidolia." Cortex 53: 60-77.

NETTLE, Daniel, Zoe HARPER, Adam KIDSON, Rosie STONE, Ian S. PENTON-VOAK a Melissa BATESON. 2013. „The Watching Eyes Effect in the Dictator Game: It's Not How Much You Give, It's Being Seen to Give Something." Evolution and Human Behavior 34(1): 35-40.

NIWA, Yuki, Kai HIRAISHI a Ryo ODA. 2011. „A Mirror Has No Effect in Giving in the Dictator Game." Letters on Evolutionary Behavioral Science 2(1): 16-19. 
SILVIA, Paul J. a Ann G. PHILLIPS. 2013. „Self-Awareness Without Awareness? Implicit Self-Focused Attention and Behavioral Self-Regulation." Self and Identity 12(2): 114-127.

TRIVERS, Robert L. 1971. „The Evolution of Reciprocal Altruism.” The Quarterly Review of Biology 46(1): 35-57.

VÁGNEROVÁ, Marie. 2008. Vývojová psychologie I. Dětství a dospívání. Praha: Karolinum.

WEDEKIND, Claus a Victoria. A BRAITHWAITE. 2002. „The Long-Term Benefits of Human Generosity in Indirect Reciprocity.” Current Biology 12(12): 1012-1015.

ŽIHLAVNÍKOVÁ, Romana, Andrej MENTEL a Ivan H. TUF. 2014. „Som pred zrkadlom lepší?” ProFil, doplňkové číslo: 82-88. Cit. 26. ledna 2015 (http://www.phil.muni.cz/journals/index.php/ profil/article/view/1000).

\section{Autoři}

Andrej Mentel je výskumným pracovníkom Ústavu sociálnej antropológie Fakulty sociálnych a ekonomických vied Univerzity Komenského v Bratislave. Venuje sa evolučnej a lingvistickej antropológii a kvantitatívnym metódam v sociálnych vedách.

Kontakt: andrej.mentel@gmail.com

Romana Žihlavníková dokončuje štúdium jednoodborovej psychológie na Univerzite Palackého v Olomouci. Pracuje ako lektorka v občianskom združení ZdrSEM. Výskumne sa zaoberá morálkou z evolučného a neurobiologického pohl'adu.

Kontakt: zihlavni@gmail.com 


\section{Príloha - výpočty jednotlivých štatistík}

\section{Štúdia 1 - vnútrosubjektové usporiadanie}

Pre výpočet výsledkov pri dizajne založenom na jednej skupine je dôležité rozlíšit dva druhy párov možných výstupov, ktoré môžeme zapísat' do kontingenčnej tabul'ky (Tab. A.1): Konkordantné (súhlasné) páry označujú tých participantov, ktorí sa v oboch administráciách zachovali rovnako ( $\mathrm{v}$ oboch poslúchli, resp. porušili pravidlo). Ich počty tu označujeme ako $\mathrm{C}_{1}$ a $\mathrm{C}_{2}$. Relevantnú informáciu však pre nás nesú zvyšné dve dvojice výsledkov - diskordantné (nesúhlasné) páry, ktorých počty v tabul'ke označujeme ako R a S. Intuitívne je jasné, že vplyv prítomného zrkadla na korekciu správania bude tým vyšší, čím bude hodnota $\mathrm{R}$ väčšia než hodnota $\mathrm{S}$, teda čím viac bude takých, ktorí v preteste pravidlo porušili, no v postteste mu vyhoveli, než naopak.

Tabul'ka A.1: Kontingenčná tabul'ka pri párovom (within-subject) dizajne

\begin{tabular}{|l|l|c|c|}
\hline \multirow{2}{*}{ Porušil pravidlo } & \multicolumn{2}{c|}{ Posttest: So zrkadlom } \\
\cline { 3 - 4 } & Vyhovel pravidlu & \\
\hline \multirow{2}{*}{ Pretest: Bez zrkadla } & Porušil pravidlo & $\mathrm{C}_{1}$ & $\mathrm{R}$ \\
\cline { 2 - 4 } & Vyhovel pravidlu & $\mathrm{S}$ & $\mathrm{C}_{2}$ \\
\hline
\end{tabular}

Pomer šancí v tomto prípade počítame podl’a jednoduchého vzt’ahu (Kirkwood a Sterne 2008: 217):

$$
O R=\frac{R}{S}
$$

V d'alších výpočtoch budeme pracovat' s prirodzeným logaritmom pomeru šancí. Odhad štandardnej chyby logaritmu pomeru šancí použijeme Woolfovu aproximáciu:

$$
S E(\ln O R)=\sqrt{\frac{1}{R}+\frac{1}{S}}
$$

Napokon na odhad 95\% intervalu spol'ahlivosti potrebujeme odhadnút' chybový faktor EF:

$$
E F=\exp (1,96 \times S E(\ln O R))
$$

Kvantil normálneho rozdelenia (z-skóre) potom vyplýva z jednoduchého vzt’ahu:

$$
z=\frac{\ln O R}{S E(\ln O R)}
$$

Napokon pre 95\% interval spol'ahlivosti platí:

$$
C I=\left\langle\frac{O R}{E F} ; O R \times E F\right\rangle
$$




\section{Štúd ia 2}

V druhej štúdii, v ktorej delíme vzorku na pracovnú a kontrolnú skupinu, postupujeme pri výpočte pomeru šancí odlišne. Kontingenčná tabul'ka zhrňujúca pozorovania má podobu Tab. A.2, kde riadky tvoria podmienky (hodnoty nezávisle premennej), kým stĺpce tvoria výsledky (hodnoty závisle premennej).

Tabul'ka A.2: Kontingenčná tabul'ka pri experimentálnom (between-subject) dizajne

\begin{tabular}{|l|l|c|c|c|}
\hline \multirow{2}{*}{ Porušil pravidlo } & \multicolumn{2}{|c|}{ Výsledok } & \\
\cline { 3 - 5 } & Vyhovel pravidlu & Šance & \\
\hline \multirow{2}{*}{ Podmienka } & Baseline (bezzrkadla) & $\mathrm{H}_{0}$ & $\mathrm{D}_{0}$ & $\mathrm{D}_{0} / \mathrm{H}_{0}$ \\
\cline { 2 - 5 } & Experimentálna (zrkadlo) & $\mathrm{H}_{1}$ & $\mathrm{D}_{1}$ & $\mathrm{D}_{1} / \mathrm{H}_{1}$ \\
\hline
\end{tabular}

Posledný stípec Tab. A.2 obsahuje výpočet šancí vyhovenia pravidlu najskôr pre kontrolnú (baseline) a potom pre experimentálnu podmienku. Pomer šancí v tomto prípade počítame podl'a vzt'ahu

$$
O R=\frac{\frac{D_{1}}{H_{1}}}{\frac{D_{0}}{H_{0}}}=\frac{D_{1} \times H_{0}}{D_{0} \times H_{1}}
$$

Pre d’alšie výpočty je vhodnejšie pracovat' s prirodzeným logaritmom pomeru šancí. Podobne ako v prvej štúdii, aj tu používame na odhad štandardnej chyby Woolfovu aproximáciu (Kirkwood a Sterne 2008: 164):

$$
S E(\ln O R)=\sqrt{\frac{1}{H_{0}}+\frac{1}{D_{0}}+\frac{1}{H_{1}}+\frac{1}{D_{1}}}
$$

Ostatné vzt’ahy sú rovnaké ako v predchádzajúcom prípade, takže ich nebudeme opakovat'. 